DOI: 10.17805/zpu.2019.1.20

\title{
Пьесы У. Шекспира в интерпретации сценографов на сцене Санкт-Петербургского академического драматического театра имени В. Ф. Комиссаржевской в конце XX - начале XXI века
}

\author{
Е. Н. ГРИНИНА
}

САНКТ-ПЕТЕРБУРГСКИЙ ГОСУДАРСТВЕННЫЙ АКАДЕМИЧЕСКИЙ ИНСТИТУТ ЖИВОПИСИ, СКУЛЬПТУРЫ И АРХИТЕКТУРЫ ИМЕНИ И. Е. РЕПИНА ПРИ РОССИЙСКОЙ АКАДЕМИИ ХУДОЖЕСТВ

В статье рассматриваются спектакли Санкт-Петербургского драматического театра имени В. Ф. Комиссаржевской по пьесам У. Шекспира, поставленные в конце XX - начале XXI в. В исследуемый период были поставлены три пьесы английского классика: «Ричард III», «Буря» и «Сон в летнюю ночь». 
Пьеса «Ричард III» была поставлена в 1998 г. художником А. Горенштейном, где он впервые попробовал себя в качестве режиссера. В том же году режиссер А. Морфов и художник Э. Капелюш выпустили спектакль «Буря». В 2007 г. А. Морфов вновь обратился к Шекспиру, выбрав «Сон в летнюю ночь».

Представленные версии спектаклей по произведениям У. Шекспира на сцене театра имени В. Ф. Комиссаржевской демонстрируют широту и многообразие образного видения пространственных решений, различные подходы в работе с классическим материалом. Объектом изучения является сценография спектаклей.

Ключевые слова: У. Шекспир; «Буря»; «Сон в летнюю ночь»; «Ричард III»; театр; режиссер; художник; сценография; декорация

\section{ВВЕАЕНИЕ}

【 нтерпретации пьес У. Шекспира в драматическом театре являются объектом привсегда они рассматриваются с точки зрения работы режиссеров или актеров, работы над текстом, а сценография спектаклей исследуется лишь как часть общего замысла. Художественно-декорационному оформлению спектаклей внимание чаще всего уделяется в контексте режиссерских задач. В данной статье анализируются постановки пьес У. Шекспира с точки зрения их художественно-пластического решения.

Сценография спектаклей по пьесам Шекспира не стала еще объектом комплексного изучения. Авторитетным исследованием, посвященным художественному решению спектакля «Буря» на сцене театра имени В. Ф. Комиссаржевской, является работа М. С. Фоминой (Уильям Шекспир «Буря» ..., 2007). Можно также назвать публикации А. С. Овәс (Овэс, 2001: Электронный ресурс), Э. А. Кузнецова (Кузнецов, 2000: Электронный ресурс), которые рассматривают творческий метод Э. Капелюша, в том числе оценивают и работу над спектаклем «Буря». В ряде статей в периодических изданиях упоминается работа художников Т. Светозарева над спектаклем «Сон в летнюю ночь» и А. Горенштейна над спектаклем «Ричард III».

Целью данной статьи является изучение художественно-декорационного оформления спектаклей по пьесам У. Шекспира на сцене театра имени В. Ф. Комиссаржевской в период с 1998 по 2007 г., выявление особенностей творческого метода театральных художников. Внимание привлекают художественные приемы сценографов, создающих интерпретации пьес «Буря», «Сон в летнюю ночь», «Ричард III», и стилистические особенности их постановок.

\section{СЦЕНОГРАФИЯ Э. КАПЕАЮША В СПЕКТАКАЕ «БУРЯ»}

Аля болгарского режиссера А. Морфова постановка пьесы У. Шекспира «Буря» в 1998 г. стала дебютом на российской театральной сцене. Он предложил свое прочтение классической пьесы, представил свое философское размышление о современном мире: «Мне хотелось воплотить в спектакле новые идеи, ощущения шекспировской философской сказки. Наступает момент, когда каждый человек должен осмыслить в высшем философском плане - свою жизнь и то, что происходит в мире после кардинальных перемен. ...Когда все идолы разрушены и низвергнуты. Именно в это время человек должен обратиться к самому себе, к собственному прошлому и настоящему и, по возможности, представить себе будущее» (Александр Морфов ... , 2004: 11). Особенное и значительное место в этом спектакле занимает работа художника Эмиля Капелюша. М. Фомина называет театрально-художественный метод работы Морфова и Капелюша над этим спектаклем «концептуальным», она справедливо отмечает, что их союз - союз режиссера и художника - продемонстрировал «игро- 
вую режиссуру в сочетании с игровой сценографией» (Уильям Шекспир «Буря» ... , 2007: 32). Черное пространство практически обнаженной сценической коробки становится мастерской, где создатели совместно рождают, пишут, рисуют, играют, наверное, самую загадочную пьесу великого англичанина, последнюю его пьесу, ставшую его последним размышлением о бытии и мире.

Пьеса полна чудесных событий. С их помощью Шекспир демонстрирует нам круговерть человеческих деяний, показывает различные людские пороки, раскрывая всю гамму человеческих чувств. На этом странном острове красота соседствует с уродством, а благородство с низостью. Шекспир, олицетворяя себя с Просперо, оставляет назидание потомкам. Счастливый конец этой сказки все же имеет горькое послевкусие, автор прощается с театром, ставя многоточие. Такое же многоточие ставит в конце и режиссер: в финале спектакля оказывается, что это был то ли сон, то ли сказка, рассказанная отцом своей дочери.

Подхватывая поэтическую интонацию Шекспира, режиссер и художник решают представить сцену в виде гигантского сказочного корабля, дрейфующего в огромном черном пространстве. Она максимально свободна от декораций, только черная «одежда сцены», деревянные балки - основной элемент декорации и большое количество реквизита.

Шестнадцать деревянных балок, по восемь с правой и с левой стороны, свисают с колосников, подвязанные тугими корабельными канатами, за которые их раскачивают актеры согласно партитуре спектакля, созданной Морфовым и Капелюшем. Художник и режиссер намеренно делают открытым фактический процесс создания будущей мистерии, впускают зрителей в театральную кухню. «Нам хотелось показать красоту этого пространства, сцены - как документ, как рукопись, как старый манускрипт», - говорит Капелюш (там же).

Именно деревянные балки становятся доминантой спектакля. Они будут существовать на сцене подобно живому организму, вскидываясь от возмущения, поднимая на дыбы морскую стихию или тихонько качаясь, создавая иллюзию вечернего бриза. На этих балках, как на качелях, будет раскачиваться, «летать» волшебный дух воздуха Ариэль. Большой белый парус широким живописным мазком раскроется в сцене бури, и Ариэль полетит с ним вместе, перескакивая с реи на рею. По решению художника, именно эти шестнадцать вертикалей, то скрещиваясь, то размыкаясь, и создают визуальный ряд. Как трубы огромного органа, они «выдувают» разные музыкальные интонации и темы - так создается единство формы и звука, музыка вплетается в художественное решение пространства.

Капелюш в оформлении использует множество мелких деталей. На сцене предметы из стекла: призмы и конусы разных форм и размеров, шары. Все это магические кристаллы Просперо, сквозь них он видит прошлое и будущее. Пропуская свет через грани стекла, Капелюш гипнотизирует зрителей, погружает их в волшебный мир иллюзии. Задний план сцены оформлен пластиковыми зеркальными панелями. Отражающиеся в них балки причудливо преломляются и становятся похожими на фантастические деревья. В центре стеклянный шар, как маятник. Художник создает поэтический образ волшебника Просперо. Аисты, словно страницы книг, летят с колосников в финале второго акта. Художник и режиссер создают образ автора пьесы, поэта, его поэтический мир.

В действии участвуют два больших черных шара, с ними контактируют герои. Один из них похож на вулканический осколок или метеорит, с резким, острым рельефом - 
он появляется в сценах с участием Просперо. Аругой - как будто склеенный или залатанный, становится олицетворением земного шара. Фердинанд и Миранда обнимают шар, объясняясь друг другу в любви. Он - то, что объединяет героев пьесы. Капелюш «создает среду, в которой актеру психологически удобно, провоцирует те или иные душевные состояния. Актер для Капелюша - вертикаль, модуль, но в большей степени духовная субстанция, живая и изменчивая, ежесекундно влияющая на бытие декорации. Подобно модельерам, строящим костюм прямо на модели, он одевает сцену “на актера”» (Овэс, 2001: Электронный ресурс).

Сценическое пространство «Бури» - самостоятельный художественный объект, имеющий разные смыслы и метафоры в контексте режиссерской мысли. Э. Кузнецов считает, что декорация «Бури» - всего лишь элемент действия, он пишет, что «сценография "Бури" - это отвлеченная трактовка фантастических обстоятельств» (Кузнецов, 2000: Электронный ресурс). Но ведь именно декорация в этом спектакле создает образ мира и человека, живущего в нем. Аеревянные реи задают ритм и настроение, запускают интригу, раскручивают колесо судьбы. Цейтмотивом звучит кантата «Carmina Burana» К. Орфа, именно она заставляет главного персонажа всей декорации - деревянные реи - двигаться как по нотам. Не случайно, самое знаменитое произведение Орфа, написанное им по средневековым рукописям, стало главной музыкальной темой спектакля. Символом непостоянства человеческой судьбы для композитора стало никогда не останавливающееся крутящееся колесо фортуны. Именно это колесо запускает в движение деревянные реи, вздымает паруса. Маятниками раскачиваются в глубине сцены стеклянные шары, отсчитывая время. Колдовство происходит теперь не только над героями пьесы, волею Просперо попавшими на остров, но и над зрителями в зале. Реи и маятник на авансцене задают ритм как всему спектаклю, так и каждой отдельной сцене. Таким образом, каждый предмет на сцене становится знаковым, у каждого из элементов реквизита свой «выход», своя «роль».

Капелюшу свойственно монохромное видение пространства. Костюмы яркими цветными пятнами врываются в черно-белое пространство сцены. Работая над образами героев пьесы, художник опирался на классическое, традиционное восприятие шекспировских персонажей, используя элементы мужского костюма конца XVI начала XVII в. в сочетании с современными одеждами. Аля Просперо и Миранды он создал авторские костюмы, привнеся в них элементы природных мотивов. Просперо - маг, ученый, герцог. Его платье похоже на одежды средневековых алхимиков, но хранит признаки царственной особы. Рукотворное платье Миранды подчеркивает характер принцессы острова, ее юность, наивность, чистоту и открытость. Она - часть природы. «Образ формируется обликом персонажа, его костюмом. Я решил, что костюмы надо придумывать как коллекцию» (Уильям Шекспир «Буря» ..., 2007: 37).

Сценическое оформление спектакля «Буря» может восприниматься совершенно самостоятельно, отдельными картинами. Графика Э. Капелюша визуализируется на сцене. Классическое произведение мировой драматургии не осовременивается, упрощая наш взгляд на него, в нем художник находит темы вечные для людей и показывает нам пространство, придуманное классиком, не имеющим четких географических координат, вне времени. Увлекая зрителей сказочными превращениями, наполняя сцену магическими предметами, художник иллюстрирует сказку Шекспира, в то же время оставляет ее практически пустой. Все - сон, мираж. Подул ветер с моря - и как будто все испарились. И сказочно, и грустно замирает сцена в декорации Капелюша. Перед нами интерпретация картины мира, метафора времени, увиденная режиссером и ху- 
дожником в пьесе Шекспира. Хаос и пустота, тревожное ожидание неизвестного на пороге нового времени. История циклична, мир не меняется, истинные ценности остаются прежними, только люди носят другие одежды и слушают другую музыку.

\section{СЦЕНОГРАФИЯ Т. СВЕТОЗАРЕВА В СПЕКТАКАЕ «СОН В АЕТНЮЮ НОЧЬ»}

В 2007 г. А. Морфов и художник из Македонии Т. Светозарев представили свою версию «Сна в летнюю ночь». Снова сцена театра была отдана во власть шекспировским феям и эльфам. А. Азимов в комментариях к пьесе размышляет об особенностях названия ее на языке оригинала и о неточностях русского перевода. "A Midsummer Night's Dream», время летнего солнцестояния заключено в названии. Это ночь безумств, время, когда с людьми происходят самые неожиданные вещи. Отчасти, по мнению А. Азимова, с ночью, подобной этой, связывает Шекспир события, описанные в пьесе (Азимов, 2007: 25).

Задача была создать сказку. Волшебство, творимое на сцене, должно было распространяться и на зрительный зал. Сцена представляет собой «черный кабинет», пространство сцены практически пустое. Боковые черные стенки выполнены из глянцевого пластика с внутренней подсветкой. Зеркальная фактура стен и планшета создает дополнительный иллюзорный әффект, усиливающийся за счет отражения на них света, преломления его сквозь дым. Эффект звездного ночного неба создан при помощи синих светодиодных лампочек на заднике и на боковых стенках крутящихся пластин. Таким образом, вся сцена превращается в бесконечное звездное пространство. Оно как будто втягивает не только героев пьесы, но и зрителей в зрительном зале. Задачей создателей спектакля было воплотить на сцене фантазию на тему волшебного леса, а не разукрашивать сцену на манер романтичных картин викторианской эпохи.

Оформление сцены представлено преимущественно реквизитом. Большой светящийся месяц в колесе из алюминиевых труб - на нем будут восседать и качаться лесные феи и эльфы - герои пьесы. По замыслу режиссера и художника, он должен соединять небесный мир, мир богов, и мир людей. В волшебную ночь луна в виде растущего месяца спускается на землю к людям, и волшебные существа на ней. К колосникам подвешен круг, выполненный из металлических труб. Он представляет собой галерею с ограждениями, пол в нем изготовлен из прозрачного пластика, отчего должно создаваться впечатление, что находящиеся на нем герои как будто парят в воздухе. По замыслу художника, это место обитания царя эльфов Оберона и царицы фей Титании. Круг разделяет мир земной и волшебный. Это воздушный мост, по которому ходят Титания, Оберон, мальчик-паж. Интересная идея художника тем не менее выглядит неоправданно громоздкой и тяжелой. Гораздо более интересно и правильно с точки зрения первоначальной идеи тема этих эфемерных созданий была воплощена создателями на гастролях. Так, в Пловдиве спектакль игрался на сцене древнего античного театра Teatro Romano, построенного в эпоху правления императора Трояна. Актеры играли на втором ярусе сохранившихся стен театра, на фоне настоящего звездного неба. Античные стены, древние камни сами прекрасно работали на образы. В другом случае, также на гастролях, спектакль играли в помещении современного театра, где по ряду технических причин металлический круг не использовался, его заменил помост, затянутый черной тканью, стоящий на фоне черного задника и кулис. Эффект оказался точнее - казалось, что герои в темноте на фоне звездного неба действительно идут по воздуху. 
Светозарев попытался наполнить сцену техническими механизмами, которые бы создавали иллюзию волшебства: фея на роликах, крутящиеся месяцы, светящиеся шары, гигантские крылья бабочки за спиной Титании. В данном случае можно говорить о попытке, желании художника освоить сценическое пространство для волшебной сказки про любовь с превращениями в сумасшедшую летнюю ночь где-то близ Афин.

\section{СЦЕНОГРАФИЯ А. ГОРЕНШТЕЙНА В СПЕКТАКАЕ «РИЧАРА III »}

Сценическую версию трагедии У. Шекспира «Ричард III» поставил художник Александр Горенштейн в 1998 г. Необычность постановки в том, что в качестве сценической площадки было выбрано пространство парадной лестницы театра, зрительские места располагались в фойе у подножья лестницы. В спектакле заняты всего три актера. Спектакль начинается как приготовление к похоронам Ричарда - две актрисы носят доски, инструмент для того, чтобы сколотить гроб. По версии Горенштейна, Ричард (в исполнении народного артиста России М. Матвеева) вспоминает свою жизнь и деяния, находясь на смертном одре. Но его монологи, его диалоги с героями пьесы - не покаяние.

Главным художественным объектом выступала лестница. Оформление было минимальным. Все внимание должно было быть сосредоточено на актерах. Аве актрисы исполняли роль хора на манер древнегреческого театра. Это было нечто среднее между площадным театром шекспировской поры и символистским театром начала XX в. Актрисы с лицами-масками меняли костюмы, которые становились декорационным оформлением, символическим живописным обозначением событий, происходивших с главным героем. Спектакль, по сути, представлял собой монологи короля, его размышления, воспоминания, сны, безумие... Все действие, как указано в программке к спектаклю, представлено картинами, всего их было 15. Ааже читая их названия: Крещение, Кларенс, Хестингс, Аеди Анна, Королева Анна и т. А., невольно возникают зрительные образы и ассоциации с портретами королей и придворных, тогдашняя семейная хроника коронованных особ европейских государств.

Горенштейн иллюстрировал монологи Ричарда, прибегая то к символу, то к метафоре. В определенные моменты на лестнице, как на жизненном этапе, важными становились различные элементы реквизита, использовались плотные шторы и тюль, зеркала. Художник использовал возможности света при освещении различных форм и фактур. Так, золотой трон Ричарда, стоящий на верхней площадке лестницы, при определенном освещении оказывался креслом, грубо сколоченным из неотесанных гнилых досок. Горенштейн создавал одновременно условный художественный и поэтический театр, одним из главных героев становилось слово, шекспировский текст. Режиссер использовал кукол в действии - прием театра старой елизаветинской Англии. Актеры по-скоморошьи играли перчаточными куклами, иллюстрируя кровавые деяния короля. Режиссер, стремясь выразить бестелесность образов, воспользовался опытом художников условного театра рубежа XIX-XX вв. Актрисы в бесформенных чехлах из мешковины становились то частью пластической композиции и элементом художественного оформления, то олицетворением судьбы главного героя, безликими образами, возникающими в сознании Ричарда, они его alter ego, голоса истины и те, с кем в постоянном и непримиримом споре.

Перед зрителями представал театр художника. Горенштейн не столько интерпретировал пьесу Шекспира, сколько, «рисовал»ее, представляя события из истории Англии. Образ лестницы в постановке доминировал, являясь единой пластической сре- 
дой. Она захватывала, вела действие, помогала актеру в создании образа, являясь метафорой и олицетворением судьбы.

\section{ЗАКАЮЧЕНИЕ}

Подводя итог, отметим, что пьесы Шекспира дают безграничные возможности для режиссеров и театральных художников для их интерпретации. Особое внимание мы уделили художественно-декорационному оформлению спектаклей по пьесам Шекспира в одном театре разными художниками. Сложно однозначно определить стиль декорационного оформления представленных спектаклей. Художественное оформление Капелюша поэтично. Аекорация здесь - образ, становящийся самостоятельным действующим лицом, метафорой. Светозарев представил современный дизайнерский подход к оформлению спектакля, уделяя основное внимание механическим и визуальным эффектам для создания атмосферы сказочного леса. Спектакль Горенштейна рассмотрен как пример театра художника и пример освоения альтернативного сценического пространства, спектакль малой формы. Горенштейн представляет в спектакле «Ричард III» систему образов, решенных через художественные средства. Актеры становятся одновременно и создателями образов персонажей пьесы, и неотъемлемыми элементами художественного решения пространства.

\section{СПИСОК АИТЕРАТУРЫ}

Азимов, А. (2007) Путеводитель по Шекспиру. Греческие, римские и итальянские пьесы / пер. с англ. Е. А. Каца. М. : ЗАО «Центрполиграф». 716 с.

Александр Морфов: Честное занятие искусством - это авантюра (2004) / Беседу с глав. реж. театра им. В.Ф. Комиссаржевской вела Т. Ткач // Культура. 9-15 декабря. № 48. С. 11.

Кузнецов, Э. (2000) Эмиль Капелюш, или разомкнутое пространство [Электронный ресурс]// Петербургский театральный журнал. № 22. URL: http://ptj.spb.ru/archive/22/the-petersburgprospect-22-3/emil-kapelyush-ili-razomknutoe-prostranstvo/ (дата обращения: 02.12.2018).

Овәс, $\Lambda$. (2001) Они не делили город на зоны влияния... [Электронный ресурс]// Петербургский театральный журнал. №1 (23). URL: http://ptj.spb.ru/archive/23/the-petersburg-prospect23-4/oni-nedelili-gorod-nazony-vliyaniya (дата обращения: 02.12.2018).

Уильям Шекспир «Буря». Эмиль Капелюш. Сценография (2007): По спектаклю Санкт-Петербургского академического драм. театра им. В. Ф. Комиссаржевской: [книга-альбом] : пер. с англ. / авт. и рук. проекта В. Е. Аевтов ; при участии М. С. Фомина ; пер. М. Аонского ; ил. Э. Б. Капелюш ; авт. текста Г. В. Коваленко, М. С. Фомина. СПб. : Информ.-издат. агентство «ИК». 119 с.: цв. ил., фот.

Аата поступления: 21.12.2018 2.

INTERPRETATION OF W. SHAKESPEARE'S PLAYS ON THE STAGE OF V.F. KOMISSARZHEVSKAYA SAINT PETERSBURG ACADEMIC DRAMA THEATER, IN THE LATE $20^{\text {th }}-$ EARLY $21^{\text {st }}$ CENTURIES

\section{E. N. GRININA}

Repin St. Petersburg State Academic Institute of Painting, SCULPTURE AND ARCHITECTURE, RUSSIAN ACADEMY OF ARTS

The paper considers the productions of W. Shakespeare's plays at V. F. Komissarzhevskaya Drama Theater staged in the early 20th - late 21st centuries. During the period in question, three plays by the English classic playwright were staged: "Richard III", "The Tempest" and "A Midsummer Night's Dream".

The play "Richard III" was staged in 1998 by artist A. Gorenshtein, which was his first experience as a stage director. That same year, stage director A. Morfov and artist E. Kapelyush produced their 
performance "The Tempest". In 2007, A. Morfov appealed to Shakespeare's plays once again choosing "A Midsummer Night's Dream".

The renditions of the above performances created after W. Shakespeare's plays at the V. F. Komissarzhevskaya Theater demonstrate not only the broad view and diversity of imaginative vision of spatial solutions, but also various approaches to work with classical pieces. The object of study is the stagecraft of the performances.

Keywords: W. Shakespeare; “The Tempest”; “A Midsummer Night's Dream”; "Richard III”; theater; stage director; artist; stagecraft; scenery

\section{REFERENCES}

Azimov, A. (2007) Putevoditel' po Shekspiru. Grecheskie, rimskie i ital'ianskie p'esy / transl. from Engl. by E. A. Kats. Moscow, ZAO «Tsentrpoligraf». 716 p.(In Russ.).

Aleksandr Morfov: Chestnoe zaniatie iskusstvom - eto avantiura (2004) / Besedu s glav. rezh. teatra im. V.F. Komissarzhevskoi vela T. Tkach. Kul'tura, 9-15 December, no. 48, p. 11. (In Russ.).

Kuznetsov, E. (2000) Emil' Kapeliush, ili razomknutoe prostranstvo. Peterburgskii teatral'nyi zhurnal, no. 22 [online] Available at: http://ptj.spb.ru/archive/22/the-petersburg-prospect-22-3/ emil-kapelyush-ili-razomknutoe-prostranstvo/ (access date: 02.12.2018).

Oves, L. (2001) Oni ne delili gorod na zony vliianiia... Peterburgskii teatral' nyi zhurnal, no. 1 (23) [online] Available at: http://ptj.spb.ru/archive/23/the-petersburg-prospect-23-4/oni-nedelili-gorod-nazony-vliyaniya (access date: 02.12.2018). (In Russ.).

Uil'iam Shekspir «Buria». Emil’ Kapeliush. Stsenografiia (2007): Po spektakliu Sankt-Peterburgskogo akademicheskogo dram. teatra im. V. F. Komissarzhevskoi: [kniga-al'bom] : per. s angl. / avt. i ruk. proekta V. E. Levtov ; pri uchastii M. S. Fomina ; per. M. Donskogo ; il. E. B. Kapeliush ; avt. teksta G. V. Kovalenko, M. S. Fomina. St. Petersburg, Inform.-izdat. agentstvo «LIK». 119 p. (In Russ.).

Submission date: 21.12.2018.

Гринина Елена Николаевна - аспирант факультета теории и истории искусств Санкт-Петербургского государственного академического института живописи, скульптуры и архитектуры имени И. Е. Репина при Российской академии художеств. Адрес: 199034, Россия, г. СанктПетербург, Университетская наб., А. 17. Тел.: +7 (812) 328-01-13. Эл. aдpec: grilena@inbox.ru. Научный руководитель - А-р искусствоведения С. М. Грачева.

Grinina Elena Nikolayevna, Postgraduate Student, Faculty of Theory and History of Arts, Repin St. Petersburg State Academic Institute of Painting, Sculpture and Architecture, Russian Academy of Arts. Postal address: 17, Universitetskaya Emb., St. Petersburg, Russian Federation, 199034. Tel.: +7 (812) 328-01-13. E-mail: grilena@inbox.ru. Scientific Advisor - S. M. Gracheva, Doctor of Arts. 